\title{
Ethnic Intermarriage and Social Cohesion. What Can We Learn from Yugoslavia?
}

\author{
Jeroen Smits
}

Accepted: 3 May 2009/Published online: 28 May 2009

(C) The Author(s) 2009. This article is published with open access at Springerlink.com

\begin{abstract}
Social cohesion theory is tested using data on ethnic intermarriage in former Yugoslavia. Before the disintegration of Yugoslavia, the proportion of marriages outside the own ethnic group was generally low, but in this respect large differences among the groups existed. The proportion of mixed marriages with a Serbian partner was much higher among the Montenegrins and Hungarians than among the Muslims, Slovenes, or Albanians. The findings are largely in line with the predictions of social cohesion theory that intermarriage reduces the probability of violent conflict among social groups. Besides proportions of mixed marriages, loglinear parameters are presented. These parameters show that percentages not always give a good indication of the social distances among groups. The boundaries of the largest ethnic groups, the Serbians and Croatians, were less closed than their rather low intermarriage rates suggested. The social distance between the Hungarians and the Serbians, on the other hand, was larger than expected on the basis of their intermarriage rates. The findings stress the importance of including information on ethnically mixed marriages into models of ethnological monitoring and early warning systems for ethnic conflicts.
\end{abstract}

Keywords Ethnic intermarriage - Yugoslavia - Social cohesion - Social distance · Conflict

\section{Introduction}

During the tragic ethnic wars of the 1990s in the republics of former Yugoslavia, the media regularly paid attention to the existence of mixed marriages between members of the ethnic groups that were so heavily fighting against each other. In such media reports generally detailed information was given about the situation of one (or a small number of) mixed couple $(s)$, but generally no figures were presented on the total number of ethnically mixed marriages in the country. Therefore, no insight was given in the degree to which such

\section{J. Smits $(\bowtie)$}

Nijmegen Centre of Economics (NiCE), Institute for Management Research,

Radboud University Nijmegen, Nijmegen, The Netherlands

e-mail: j.smits@fm.ru.nl 
marriages were normal of abnormal in former Yugoslavia. This is regrettable. Intermarriage is an important indicator of the quality of the relationships among groups in a society. Information on the strength of the intermarriage tendency among the ethnic groups in former Yugoslavia might learn us how good or bad the relationships among these groups were in the period before the disintegration of the country. In addition, such information could be used to test sociological integration theories.

In the sociological literature, the existence of mixed marriages between the members of groups in a society is generally expected to reduce the probability of violent conflicts among those groups and to increase the social cohesion of that society (for example, Merton 1941; Blau and Schwartz 1984; Gündüz-Hoşgör and Smits 2002; Monden and Smits 2005). From the perspectives of these theories, the Yugoslav ethnic conflicts would be much more difficult to comprehend if intermarriage was common among the members of the ethnic groups who have been fighting so heavily against each other, than if intermarriage was rare among these groups. Studying ethnic intermarriage in former Yugoslavia, therefore, might contribute to the improvement of sociological theories in this area. Such an analysis might also produce information which might be helpful in defining potential ethnic conflict areas in the world and developing models for "ethnological monitoring" and "early warning" for ethnic conflicts in multi-ethnic societies (Davis and Gurr 1998; Verstegen 1999; Austin 2003).

In the literature on ethnic intermarriage in Yugoslavia written during the Communist period, the impression was raised that intermarriage was a rather common phenomenon in this country, and that the number of mixed marriages was increasing (Bromlei and Kashuba 1982; Petrovic 1986; Rieff 1995). However, this impression was challenged by Botev (1994). On the basis of data from the Yugoslav population administration, Botev shows that only about $12 \%$ of the marriages which were concluded in Yugoslavia between 1961 and 1989 was mixed with regard to the ethnic backgrounds of the partners. This percentage varied somewhat among the Yugoslav republics, from 5\% in Kosovo to $28 \%$ in Vojvodina, and-most importantly-it remained at about the same level in the decades before the breakdown of Yugoslavia. Besides presenting intermarriage percentages for the Yugoslav republics, Botev also performs a loglinear analysis which gives additional information about intermarriage preferences. The loglinear parameters showed that the preference for a marriage outside the own ethnic group was generally low, and that the Serbians and Croatians in this respect were the most open groups.

The findings of Botev do not give much insight in the validity of social cohesion theory. The percentages he presents are for the republics as a whole and not for separate ethnic groups. Because most republics are inhabited by more than two ethnic groups, and the members of most ethnic groups are spread out over several republics, these percentages do not say very much about the intermarriage tendencies of separate ethnic groups. Botev's loglinear parameters do give information about separate ethnic groups, but only about the tendency to marry within the own ethnic group. Precise information about "whom marries whom" for individuals marrying outside their ethnic group is lacking in his paper.

The figures presented in the current paper give more insight in the validity of social cohesion theory, because they apply both to marriages within and between specific ethnic groups. To find out whether and to what extent the events in former Yugoslavia support or refute social cohesion theory, we compare the intermarriage tendencies of ethnic groups which, in the period since the breakdown of Yugoslavia, did and the groups which did not fight against each other. Because the Serbians played a central role in most of the violent conflicts, special attention is paid to the mixed marriages in which one of the partners has the Serbian nationality. 
Using data from the 1981 Yugoslav Census, we show how many marital ties in that year existed between members of the main ethnic groups and the Serbians. Because part of these marriages were concluded long before 1981, these Census data are less fitted to indicate the strength of the tendency toward intermarriage at a certain point in time. Therefore, we will also re-analyze the data used by Botev on the ethnic groups of spouses for all marriages that were concluded in the years 1962, 1971, 1980, and 1989. To gain more insight in the strength of the tendency to marry within the own ethnic group and of the tendency to marry with a Serbian partner, we will also present loglinear parameters.

Throughout this paper we will use the term (ethnic) homogamy for the tendency to marry within the own (ethic) group. Furthermore, ethnic groups of which a large(r) part of the members tends to marry outside the own group will be called (more) open, and ethnic groups where a small(er) part of the members tends to do this (more) closed.

\section{Historical Background}

Ethnic tensions have plagued former Yugoslavia since its foundation as an independent state in 1918, after the collapse of the Austrian-Hungarian and Ottoman empires. In the new state, the nineteenth century Serbian and Croatian dream of a union of South Slaves could finally be realized. However, the nation was heavily dominated by the Serbians. As largest ethnic group and allies of the winners of World War I, they had got disproportionate control over the Yugoslav state. The resulting tensions between Serbs and Croats reached a peak during World War II, when the Germans occupied the country and part of the Croats allied with them to establish their independent 'Ustasha' state, where they exercised a reign of terror and killed over 300,000 Serbs. In response to the oppression, two significant resistance movements developed, Serbian 'Chetniks' who aimed to establish a 'greater Serbia' and communist Partisans, controlled by the communist leader Tito.

After the defeat of the Germans, Tito established the Socialist Federal Republic of Yugoslavia, as a "federation of equal nations" led by a centralized government, the League of Communists of Yugoslavia (LCY) (Sekulic et al. 1994). In spite of severe atrocities perpetrated by all sides during the war, the decades after World War II were relatively peaceful (Anderson 1995). The Tito regime addressed the ethnic sentiments by providing legal guarantees for the use of one's language and other aspects of national identity, while it at the same time tried to prevent the transference of the emotional ethnic ties to the new generation. This was done, for instance, by reducing the autonomy of the churches and bringing back the role of religion in the expression of ethnic character (Seroka 1992: 577). The government expected that modernization of the country would reduce the influence of ethnic sentiments (Hodson et al. 1994). Industrialization would replace solidarity based on ethnicity by solidarity based on class identity (Seroka 1992).

However, although the country experienced rapid modernization, accompanied by increased geographic mobility, urbanization and a general rise of the level of schooling, the deep-rooted influence of traditional ethnic and nationalist sentiments was not overcome. No broadly based sense of Yugoslav identity emerged (Simic 1991). Over time, the central government weakened and the power of the communist state bureaucracies in the republics increased (Hodson et al. 1994). The policies aimed at establishing worker self-management during the 1950s strengthened the local party bureaucracies at the cost of the central leadership (Schierup 1991). In the following years, more and more influence was transferred to the republican communist parties. A milestone in this decentralization process was the new constitution of 1974 , by which the power of the republics and their political 
elites was legally formalized (Pesic and Janic 1992). The economic crisis of the 1970s and early 1980s increased the economic gap between the more and less developed republics (Jovic 2001) and strengthened the centrifugal forces. Especially after the death of Tito in 1980, the powerless center was not able to resolve interregional conflicts and prevent them to acquire ethnic meaning (Burg 1983; Vejvoda 2004). The country quickly dissolved and after the collapse of communism in 1989-1990 the centrifugal forces got so much momentum that the country fell apart. Slovenia and Croatia unilaterally declared themselves independent on 25 June 1991. Immediately after this declaration the Yugoslav wars started.

\section{Ethnic Intermarriage}

In the sociological literature, the use of intermarriage as an indicator of the position of groups in society has a long tradition. Especially in the US much has been published about this subject. Sociologists like Merton (1941), Gordon (1964) and Blau (1977), (Blau and Schwartz 1984) consider the study of intermarriage as an important way to gain insight in the structure of ethnic and racial relationships. The existence of many marriages between the members of immigrant groups and members of groups that live already for several generations in a country has rather generally been considered to be an indication of integration and assimilation (e.g. Drachsler 1921; Gordon 1964; Alba and Golden 1986; Pagnini and Morgan 1990). In the course of the twentieth century, many empirical studies on intermarriage in the US have been published which, among others, show that in the decades after World War II the tendencies toward intermarriage with regard to national origin (Alba and Golden 1986; Lieberson and Waters 1988; Pagnini and Morgan 1990; Qian and Lichter 2001; Rosenfeld 2002), religion (Johnson 1980; Kalmijn 1991) and race (Schoen and Wooldredge 1989; Kalmijn 1993; Qian 1997; Qian and Cobas 2004) have increased.

In recent decades, there also was an increase in the number of studies on ethnic intermarriage for other countries than the US. In part, these studies were directed toward the position of ethnic groups in multi-ethnic societies, like, for example, Israel (Shavit and Stier 1994), Taiwan (Tsai 1996; Lu and Wong 1998), Singapore (Lee 1988), Turkey (Gündüz-Hoşgör and Smits 2002), and Latvia (Monden and Smits 2005). In addition, mixed marriages have been used to gain insight in the position of immigrants in traditional immigrant societies, like Australia (Jones 1991; Meng and Gregory 2005) and Canada (Jansen 1982; Kalbach 2002), and in new immigrant societies like England (Coleman 1985), France (Munoz-Perez and Tribalat 1984), and the Netherlands (Van Tubergen and Maas 2007). In general, these studies reveal rather strong tendencies toward ethnic homogamy in these countries.

Relatively little is known about intermarriage among the ethnic groups in Eastern European countries. Although it sometimes has been suggested that ethnic intermarriage might reduce the probability of ethnic conflicts in these regions (e.g. WRR 1995, p. 34), it is difficult to find empirical evidence for this notion in the literature. Besides the studies on Yugoslavia, which were mentioned in the Sect. 1 of this paper, there is a recent paper on intermarriage in Latvia (Monden and Smits 2005) which shows that before independence from Soviet Union intermarriage between Latvians and Russians was quite high (16\%) and an earlier paper on former Czechoslovakia (Boguszak and Bozon 1989) which shows that in 1984 there were very few marital relationships between Czechs, Slovaks, and Hungarians (p. 208). The authors of this last paper did not discuss the possible 
consequences of this situation for the stability of Czechoslovakia. At the time they wrote this article, it could hardly be foreseen that Czechoslovakia would fall apart along ethnic lines.

\section{Social Distance and Social Cohesion}

The number of marriages between the members of different groups in a society holds information about the nature of the contacts between those groups. If there are many marital ties between the members of different groups, there must also be other social contacts-like friendships-between them. Furthermore, the children of different groups must have the opportunity to meet each other-at school, in the neighborhood, or during leisure activities. Moreover, if intermarriage among the members of different groups is a common phenomenon, this indicates that the members of these groups accept each other as social equals (Kalmijn 1998). The number of marriages between the members of different groups, therefore, can be used as an indicator of the degree of positive of negative social contact, or "social distance" between those groups.

Once there are mixed marriages among the members of different groups, another aspect of intermarriage starts to play a role: its function as a connecting element in a society. Mixed marriages not only link together two individuals, but also the larger groups to which these individuals belong. Such marriages form a bridge between these larger groups across which family members and friends of the partners may get in touch with each other and new-group boundary transcending-personal contacts and collaborations may come into existence. For this reason, mixed marriages are expected to promote the social cohesion of societies (compare, Merton 1941; Blau and Schwartz 1984; Gündüz-Hosgör and Smits 2002; Monden and Smits 2005). Blau and Schwartz (1984), for example, state that, for the integration of different segments of a larger population (intensive) personal contacts between persons who belong to those segments are needed. According to these authors, value consensus or functional dependencies among the members of a society are not enough to create social integration, but personal ties between the members of different groups or strata are needed, and they consider marriage relationships in this respect to be best (pp. 12-13). There is also an extensive anthropological literature about the importance of intermarriage (exogamy) for the realization of social cohesion in societies that consist of a number of smaller units, like clans (e.g. Lévi-Strauss 1969; Van den Berghe 1979).

If the conclusions of this literature are correct, to reach social cohesion in countries with many different ethnic groups, friendship and marriage relationships between members of these groups would be necessary. Conversely, the outbreak of violent conflicts between ethnic groups, like in former Yugoslavia, would indicate that there were too few friendship and marital ties, to bring about stability. Therefore, the situation in former Yugoslavia can be used to test the assumption that intermarriage promotes social cohesion. If the media reports were correct and ethnic intermarriage was widespread in former Yugoslavia, this assumption would be difficult to hold. And especially so, if there were many mixed marriages between members of the ethnic groups that have been fighting so heavily in the last decade.

Before the start of our analysis, it is difficult to say how large the number (or percentage) of mixed marriages should be to get a substantial reduction of the probability of violent conflicts among ethnic groups. By comparing the number of mixed marriages with a Serbian partner between ethnic groups who did and ethnic groups who did not engage in violent conflicts with the Serbians, we hope to gain more insight in this important issue. 


\section{Structural Factors}

If we focus on the social cohesion that would be furthered by ethnic intermarriage, we are considering the consequences of these marriages. However, because we are also interested in the social distances among the Yugoslav ethnic groups, we will also pay attention to the causes of ethnic intermarriage. If there are many (few) mixed marriages among the members of different ethnic groups, this does not necessary mean that the social distances among these groups are small (large). The intermarriage chances of individuals are also influenced (restricted) by structural constraints of the marriage market (Blau 1977; Kalmijn 1998; Monden and Smits 2005).

An important structural factor is group size. All other things being equal, the probability of a coincidental meeting with somebody from a large group is higher than the probability of such a meeting with somebody from a small group (e.g. Blau and Schwartz 1984). Furthermore, the size of the smallest groups is a restrictive factor. The number of mixed marriages cannot be higher than the number of persons in the smallest group. If there are differences in group size, there will always be a number of persons in the largest group for whom no partner in the smallest group is available.

Another important structural factor is spatial segregation (Gündüz-Hosgör and Smits 2002). We cannot expect many marriages between the Slovenes in the north of Yugoslavia and the Macedonians in the south. But even if the geographical distances are small, there may be spatial segregation, for example if in a certain region some villages are solely inhabited by Albanians and other villages are solely inhabited by Serbians.

If we use intermarriage to gain insight in the social cohesion of a society, these structural factors are not very important. In that case it makes little difference whether a mixed marriage was more or less forced by the circumstances or a positive choice for a partner from that group. In both cases the marriage constitutes a cohesion-increasing link among the groups. When a larger part of the possible marital links between different ethnic groups is actually formed, this cohesion increasing effect will be stronger. The maximum number of links is reached when all members of the smallest group are married with somebody from the larger group. If we want to use intermarriage as an indicator of social cohesion in a society, we therefore have to look at the proportion of mixed marriages among the members of the smallest group.

On the other hand, if intermarriage is used as an indicator of the social distances among groups, the existing differences in size among the groups may distort the analysis. Because more marriages can be expected with individuals belonging to a large group than with individuals belonging to a small group, proportions of mixed marriages do not give a good indication of the preferences for (or aversion against) a partner from a certain group. If intermarriage is used to gain insight in the social distances among ethnic groups, therefore, looking at proportions of mixed marriages is not enough. For this purpose, measures should be used that are not influenced by differences in group size, like odds ratios or loglinear parameters.

\section{Data and Methods}

For our analysis we use published data from the 1981 Yugoslav Census (Savezni Zavod Statistiki 1991) and from the Yugoslav population administration (Savezni Zavod Statistiki 1963, 1974, 1982, 1990). From the 1981 Census we use a table in which the ethnic groups of husbands and wives are cross-classified for all existing marriages in Yugoslavia in 1981. 
The population administration data consist of tables with the ethnic groups of husbands and wives for all marriages that were registered in Yugoslavia in the years 1962, 1971, 1980 and 1989. We distinguish between eight ethnic groups: 'Montenegrins', 'Croatians', 'Macedonians', 'Muslims', 'Slovenians', 'Serbians', 'Albanians', and 'Hungarians'. With the exception of the category 'Yugoslavs', the other ethnic groups in former Yugoslavia were much smaller in size. The category 'Yugoslavs' was rather heterogeneous and its size and composition changed much in the period under study (see for example Botev 1994; Sekulic et al. 1994). For this reason we do not consider this group as a separate ethnic group in our analyses.

For each of the eight ethnic groups, we present the proportion of marriages within the own group and the proportion of marriages with a Serbian partner. These figures will show us the extent of cohesion-increasing marital ties for these groups. For the homogamous marital combinations and for the mixed marriages with a Serbian partner we will also present loglinear parameters (Agresti 1990). These parameters will give insight into the strength of the preference for a marriage within the own group and in the social distances with the Serbians.

\section{Results}

\subsection{Census 1981}

Figure 1 is based on the data from the Census of 1981. In that year, there were about four million married persons with the Serbian nationality and over two million married persons with the Croatian nationality. The other ethnic groups were (and are) much smaller. In $1981,8.6 \%$ of the married Croatians had a partner from another ethnic group. About $4 \%$ of

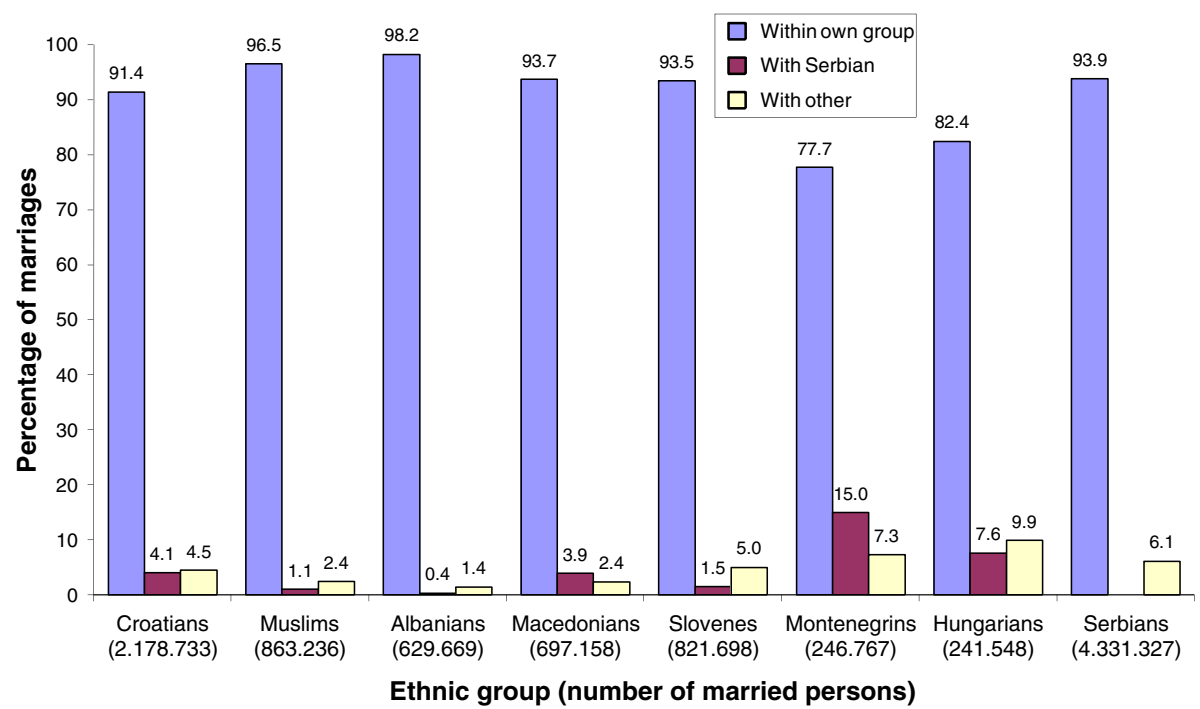

Fig. 1 Percentage of marriages within the own ethnic group, with Serbians, with members of other ethnic groups, and number of married persons, for selected ethnic groups in Yugoslavia in 1981 
them had a Serbian partner. That means that only about one in 25 Croatians was connected via a marital tie with a Serbian. Still, this is rather much compared to the Muslims and the Albanians. Of the Muslims, more than $96 \%$ was married within the own group, and only $1.1 \%$ had a Serbian partner. And the social closure of the Albanians was even stronger. Of them, more than $98 \%$ was married within the own group and only $0.4 \%$ with a Serbian partner. This means that in 1981 no more than 1 in 90 of the married Muslims and 1 in 250 of the married Albanians had a partner with the Serbian nationality.

Figure 1 further shows that with respect to the proportions of mixed marriages, the Montenegrins were closest to the Serbians. About $15 \%$ of the married Montenegrins-one in seven-had a Serbian partner. Also the Hungarians, most of which live in the Northern Serbian province of Vojvodina, were above average linked to the Serbians via marital ties.

\subsection{Yearly Concluded Marriages}

The intermarriage rates derived from the Census of 1981 show how many marital ties in that year existed among the Yugoslav ethnic groups. However, because these figures pertain to existing marriages, concluded in an earlier time period (which for the older people may be rather long ago), they do not show us the strength of the intermarriage tendencies for a specific point in time. Therefore, it is also useful to look at the new marriages that were concluded in a given year. Figures 2 and 3 present this kind of information for the years 1962, 1971, 1980 and 1989.

Figure 2 shows that the proportions of mixed marriages among the yearly concluded marriages, for all ethnic groups, are somewhat higher than in the Census data. This could mean that in the period to which these figures apply the boundaries among the ethnic groups were more open than in the more distant past. However, it is also possible that a larger proportion of the mixed marriages has ended in divorce. In the census data only existing marriages were counted.

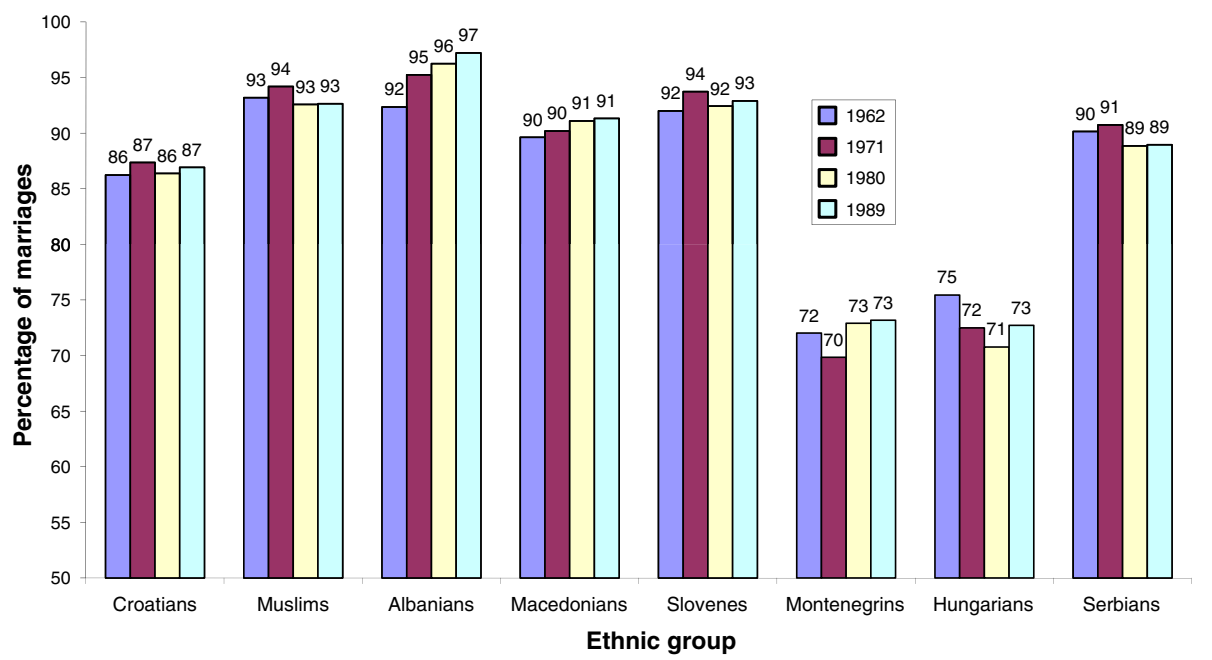

Fig. 2 Percentage of marriages within the own ethnic group concluded in 1962, 1971, 1980 and 1989, for selected ethnic groups in former Yugoslavia 


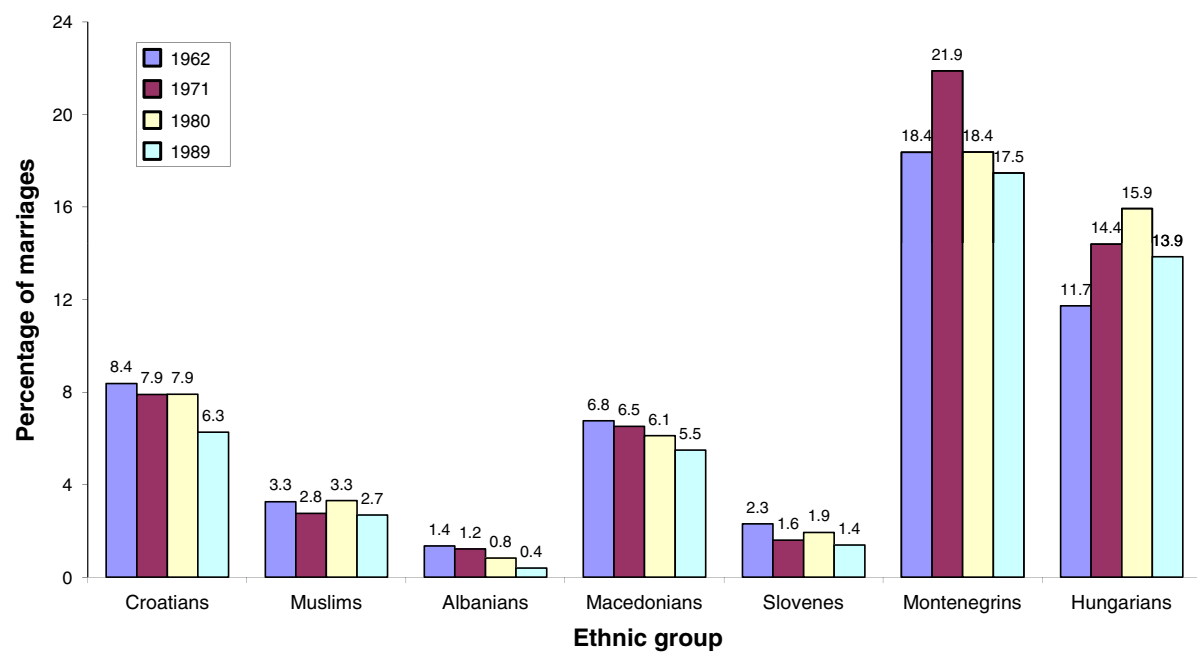

Fig. 3 Percentage of marriages with a Serbian partner, concluded in 1962, 1971, 1980 and 1989, for selected ethnic groups in former Yugoslavia

We also see in Fig. 2 that in this period of nearly 30 years the proportion of mixed marriages did not increase at all. For one ethnic groups-the Albanians-it even decreased. Whereas in 1962 about $8 \%$ of the Albanians married outside the own ethnic group, in 1989 this proportion was no more than 3\%. This increase reflects the heightened tensions between Albanians and Serbians in Kosovo, where from the 1960s on the Albanians became more and more dissatisfied with their lack of political influence and the privileged position of the Serbian minority.

With regard to the mixed marriages with a Serbian partner, Fig. 3 shows that very few marriages took place between Albanians and Serbians. In 1962, no more than $1.4 \%$ of the marrying Albanians did so with a Serbian partner. And in 1989, this proportion was no more than $0.4 \%$, or 1 in 250 . So, on the eve of the disintegration of Yugoslavia, the number of positive contacts between Albanians and Serbians probably was very low. Intermarriage between the Slovenes and the Serbians and between the Muslims and the Serbians was also very rare. The Montenegrins and the Hungarians, on the other hand, married relatively much with a Serbian partner. About one in six marrying Montenegrins and one in seven marrying Hungarians did so in the decades before the disintegration of Yugoslavia.

\subsection{Loglinear Parameters}

As we already saw in sect. 3, proportions of mixed marriages do not give a good impression of the preferences of the members of an ethnic group for a partner from another ethnic group, or, in more sociological terms, of the social distance among the groups. In this paper we, therefore, also present loglinear parameters. For the preference for a partner from the own ethnic group, such parameters were already presented before by Botev (1994), who used the data from the Yugoslav population administration on yearly registered marriages for the period 1962-1989. Botev found that the preference for a partner from the own ethnic group was lowest among the Serbians and that - in this respect- the Croats were also a relatively open group. This result differs from our findings on the basis 
of proportions of mixed marriages among the yearly concluded marriages, as presented in Fig. 2. Not the Serbians and Croatians, but the Montenegrins and Hungarians showed the highest proportions of mixed marriages. This indicates that the high proportions of marriages within the own ethnic group which we found for the Serbians and Croatians are in part due to the large size of these ethnic groups. The probability of a coincidental meeting with somebody from a large ethnic group is higher than the probability of such a meeting with somebody from a small group.

In the next section, we first replicate the findings of Botev regarding the propensity to marry within the own ethnic group, on the basis of the data from the 1981 Yugoslav Census. Next, we go a step further and include also the mixed marriages with a Serbian partner in the loglinear analysis. For this part of the analysis we will use both the 1981 Census data and the population administration data for the period 1962-1989.

\subsection{Preference for a Marriage Within the Own Group}

Table 1 presents results of a loglinear analysis of the tendency to marry within the own ethnic group for all existing marriages in 1981. The model contains both parameters which control for the differences in group size among the ethnic groups and parameters which indicate the strength of the preference for a marriage within the own group. In Table 1 we see the parameters for the tendency to marry within the own group and some fit measures of the model. Reference group for the parameters are the mixed marriage combinations, which in this model are assumed to have the same probability after control for the differences in group size. Because the number of respondents in the table is very large, the traditional statistical criterion for the fit of these models, the Likelihoodratio $\left(G^{2}\right)$ compared to its number of degrees of freedom, cannot be used in our analysis. With such a large $N$ the standard estimates become so small that even very small differences, which have no substantial meaning, become statistically significant. Therefore, Table 1 also offers an $\mathrm{r}^{2}$ statistic (Erikson and Goldthorpe 1992, 88), which shows the proportion of the-for differences in group size controlled-association in the table that is explained by the model. For the model in Table 1, this proportion is $99.52 \%$.

Table 1 shows both the logarithmic (B) and the multiplicative $(\exp (\mathrm{B}))$ versions of the loglinear parameters. The multiplicative versions are most easily to comprehend. They show how much larger or smaller the chances of a homogamous marriage are, compared to

Table 1 Logarithmic (B) and multiplicative $(\exp (B))$ parameters for the tendency to marry within the own group of selected ethnic groups in former Yugoslavia in $1981(N=5.428 .201$ couples)

\begin{tabular}{llr}
\hline Ethnic group & B & $\operatorname{Exp}(\mathrm{B})$ \\
\hline Croatians & 3.67 & 39 \\
Muslims & 6.87 & 958 \\
Albanians & 9.05 & 8545 \\
Macedonians & 5.85 & 347 \\
Slovenes & 5.64 & 281 \\
Montenegrins & 4.19 & 66 \\
Hungarians & 4.74 & 115 \\
Serbians & 3.14 & 23 \\
Average & 5.39 & 220 \\
$G^{2} / \mathrm{DF}$ & $73550 / 55$ & \\
r $G^{2}$ & $99.52 \%$ & \\
\hline
\end{tabular}


the average probability of a mixed marriage combination, after control for the differences in the numbers of married males and females among the ethnic groups. These parameters have a value between zero and infinity, with the value of one as turning point. A value higher than one indicates that the probability of a homogamous combination is higher than the probability of a mixed combination. A value between zero and one indicates the reverse. Because of the very large number of cases, all parameters in Table 1 differ significantly from one.

We see that after control for the differences in group size, the tendency to marry within the own ethnic group remains very high. On average, the likelihood of a marriage within the own group is about 220 times as high as the likelihood of a mixed combination. The parameters for the separate ethnic groups show that the tendency toward homogamy differs clearly among the groups. After control for the differences in group size, the Serbians are the most open group, followed by the Croatians. This finding is in line with the results of Botev (1994). It indicates that the relatively high proportion of homogamous marriages which we found for the Serbians and Croatians, is in part due to the fact that they are the largest ethnic groups.

The likelihood of a marriage within the own group is for the Serbians about 23 times as high as the likelihood of a mixed combination. For the Croatians, this likelihood is about 39 times as high. Table 1 further shows that also after control for group size, the Albanians and Muslims are the closest groups.

\subsection{Intermarriage with a Serbian Partner}

To gain insight in the preference for (or aversion against) a marriage with a Serbian partner, the results of a second loglinear model are presented in Table 2. This time, the model is a quasi-symmetry model (Hout 1983, p. 25). For each combination of ethnic groups, a separate parameter is estimated, with as only restriction that it is symmetric (i.e. that its value does not depend on to which ethnic group the wife belongs and to which ethnic group the husband belongs). The $r G^{2}$ value of this model $99.98 \%$.

Table 2 shows the parameters for the mixed marriage combinations with a Serbian partner. The combination Croatian-Serbian is taken as the reference category. This means that the multiplicative parameters $(\exp (B))$ indicate to what extent the likelihood of a mixed marriage with a Serbian partner for the different ethnic groups is higher or lower than this likelihood for the Croatians.

Table 2 Logarithmic (B) and multiplicative $(\exp (\mathrm{B}))$ parameters for the tendency to marry a Serbian partner of selected ethnic groups in former Yugoslavia in 1981

The combination CroatianSerbian is taken as the reference group ( $N=5.428 .201$ couples)

\begin{tabular}{lll}
\hline Ethnic group & $\mathrm{B}$ & $\operatorname{Exp}(\mathrm{B})$ \\
\hline Croatians & 0.00 & 1.00 \\
Muslims & -1.83 & 0.16 \\
Albanians & -3.31 & 0.04 \\
Macedonians & -0.61 & 0.55 \\
Slovenes & -1.53 & 0.22 \\
Montenegrins & 0.29 & 1.34 \\
Hungarians & -0.43 & 0.65 \\
$G^{2} / \mathrm{DF}$ & $2437 / 28$ & \\
$\mathrm{r} G^{2}$ & $99.98 \%$ & \\
\hline
\end{tabular}


Most ethnic groups, show a much lower tendency to marry with a Serbian partner than the Croatians. For the Macedonians and Hungarians, this tendency is about half as strong as for the Croatians. For the Slovenes and Muslims it is only 20\%, and for the Albanians even no more than $4 \%$. The Montenegrins, on the other hand, show a more than $30 \%$ higher preference for a Serbian partner than the Croatians.

For the Hungarians and the Croatians, the impression we got from the percentages in Fig. 1 differs from what we see if we look at the loglinear parameters. The social distance between Hungarians and Serbians turns out to be larger than would be expected on the basis of the percentages of mixed marriages. This indicates that the relatively high proportion of Hungarian-Serbian marriages might in part be the result of the large differences in group size among these groups. For the Croatians, on the other hand, looking only at percentages leads to an underestimation of the preference for a Serbian partner.

Figure 4 presents loglinear parameters for the combinations with a Serbian partner on the basis of the data of the Yugoslav population administration for the period 1962-1989. These parameters are also derived from a quasi-symmetry model. The $\mathrm{r} G^{2}$ value of this model is $99.96 \%$. The combination Croatian-Serbian in 1962 is taken as the reference category.

The results presented in Fig. 4 are quiet similar to those of Table 2. The Macedonians and Hungarians again take in a middle position, with a preference for a Serbian partner about half as strong as among the Croatians. And the Muslims, Slovenes and Albanians again show the lowest tendency to marry a Serbian partner. Only the parameters of the Montenegrins deviate somewhat from Fig. 4. They still have a relatively strong preference for a marriage with a Serbian partner, but, this time, that preference is about equally strong as that of the Croatians.

The changes over time in the tendency to marry a Serbian partner are not very spectacular. Among the Croatians this tendency decreases somewhat; among the Muslims it increases somewhat; but in general the figures are rather stable. This indicates that in the decades before the disintegration of Yugoslavia no large changes took place in the social distances between the Serbians and the other ethnic groups.

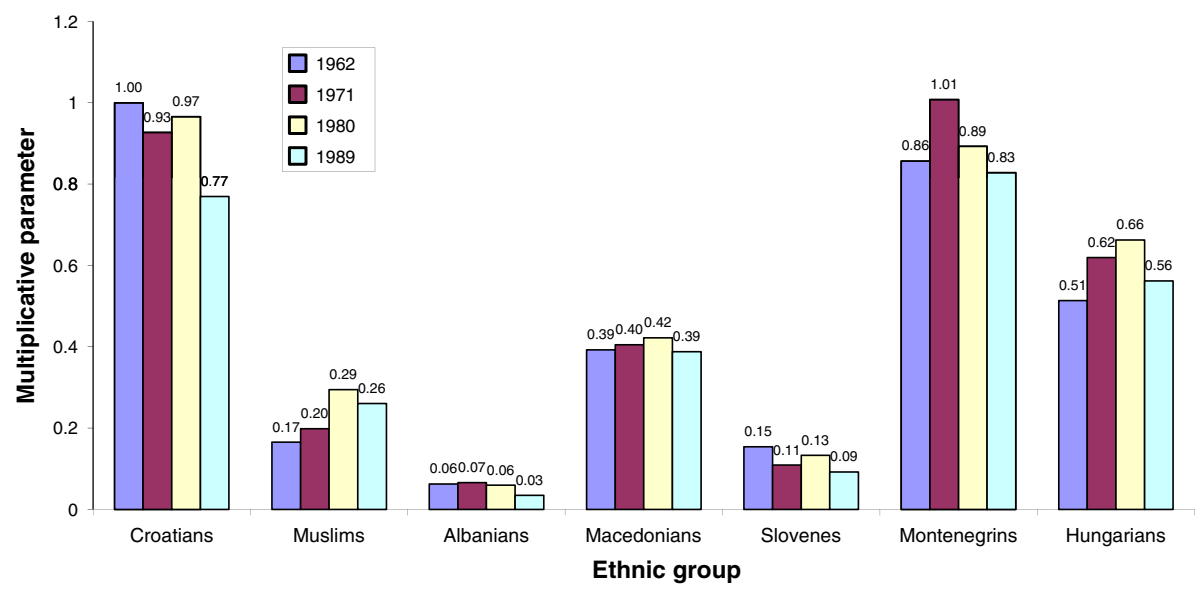

Fig. 4 Multiplicative parameters for the tendency toward intermarriage between selected ethnic groups and the Serbians in 1962,1971, 1980 and 1989. The combination Croatian-Serbian in 1962 is taken as the reference group. ( $N=670.317$ couples $)$ 


\section{Conclusions}

What can we learn from the figures on ethnic intermarriage in former Yugoslavia presented in this paper? A first important conclusion of this study is that there were indeed ethnically mixed marriages in former Yugoslavia, but that the number of these marriages was rather low. Only for two of the eight ethnic groups studied, the proportion of mixed marriages in 1981 was more than $10 \%$. And those two ethnic groups-the Montenegrins and Hungarians-were rather small, so that their marriage behavior had little influence on the total number of mixed marriages in the country. Social closure was strongest among the Albanians and Muslims. In 1981, only 1.8\% of the married Albanians and 3.5\% of the married Muslims had a partner from another ethnic background.

Second, it can be concluded that speaking only in terms of many or few ethnically mixed marriages does not do justice to reality of former Yugoslavia. Although intermarriage figures were rather low for all of the groups, still clear differences among the groups were observed. Because of the central role of the Serbians in most of the conflicts of the last decade, special attention was paid to the mixed marriages with a Serbian partner. We found that Montenegrins and Hungarians married relatively much with Serbians. In 1981, about one in seven married Montenegrins and one in 13 married Hungarians had a Serbian partner. Among the Muslims, on the other hand, the number of mixed marriages with a Serbian partner was only 1 in 90 and among the Albanians it was no more than 1 in 250 . If we look at the number of marriages concluded in a given year, the differences are rather large too. Whereas in 1989 about one in six or seven Montenegrins and Hungarians choose for a marriage with a Serbian partner, that choice was made by only one in 35 Muslims, one in 70 Slovenes and one in 250 Albanians.

Third, the differences in inclination to marry a Serbian partner are in line with what could be expected on the basis of social cohesion theory, which predicts the risk of violent conflict between ethnic groups to be lower if there are more marital 'bridges' between the groups. The Montenegrins and Hungarians, which were linked to the Serbians by most marital ties, merged initially rather easily into the Serbian dominated Yugoslav Federation. Of the three groups which intermarried least with the Serbians, the Muslims and Albanians fought heavily against the Serbians, and the Slovenes were among the first to separate from Yugoslavia and defeated the Yugoslav army in 1991. A third important conclusion of this paper, therefore, is that the unfortunate events in former Yugoslavia do not refute social cohesion theory but instead support it: more intermarriage was associated with less violent conflict.

If we combine these results with findings for Turkey, where about $8 \%$ mixed marriages could not prevent violence between Turks and Kurds (Gündüz-Hoşgör and Smits 2002), and for Latvia, where with $16 \%$ mixed marriages between Russians and Latvians no open violence occurred after the separation from Russia (Monden and Smits 2005), it seems possible to say something about the number of mixed marriages which might be necessary to get such a conflict-reducing effect. One in fifteen clearly seems to be too little, but one in six or seven might offer hope in this respect.

Of course we must keep in mind that ethnic intermarriage is only one among many factors that may play a role in any ethnic conflict. And also that lack of marital ties does not preclude peaceful coexistence. There are many examples of groups living peacefully together in the same area with hardly any marital connection. However, the reverse case, of groups with many marital connections engaging in heavy fights seems much more unlikely.

The finding that ethnic groups with relatively much marital ties were less involved in armed fighting suggests that information on intermarriage might be a useful component of 
models of ethnological monitoring and early warning systems for ethnic conflicts. For this purpose, the distinction which is made in this paper between the use of intermarriage as an indicator of social cohesion and of social distances among groups seems to be very useful. If one is interested in the cohesion improving and conflict reducing effects of intermarriage, the absolute number of marital relationships is most important and it is necessary to look at percentages of mixed marriages. The situation of maximal cohesion is reached if all married persons from the smallest group are married to someone from the largest group. Therefore, one should look at the percentage of mixed marriages among the members of the smallest group.

If, on the other hand, intermarriage is used to indicate social distance-the degree of positive or negative social contact-among ethnic groups, percentages of mixed marriages are less useful, because differences in size among the groups may be a disturbing factor. The probability of a coincidental meeting with somebody from a larger ethnic group is higher than the probability of a coincidental meeting with somebody from a smaller ethnic group. Therefore, intermarriage measures should be used that are insensitive to differences in size among the groups, like odds ratios or loglinear parameters. Using loglinear parameters, we found that the relations among the ethnic groups in terms of social distance are not completely in line with the picture we got on the basis of percentages of mixed marriages. In terms of social distance, the two largest ethnic groups, the Serbians and Croatians were found to be closer to the other groups than would be expected on the basis of the percentages of mixed marriages. The social distance between the Hungarians and Serbians turned out to be larger than indicated by the proportion of mixed marriages. In this case, the restricted marriage market of the Hungarians, because of their small group size, seems to play a role.

Open Access This article is distributed under the terms of the Creative Commons Attribution Noncommercial License which permits any noncommercial use, distribution, and reproduction in any medium, provided the original author(s) and source are credited.

\section{References}

Agresti, A. (1990). Categorical data analysis. New York: Wiley.

Alba, R., \& Golden, R. (1986). Patterns of ethnic marriage in the United States. Social Forces, 65, $202-223$. doi: $10.2307 / 2578943$.

Anderson, D. (1995). The collapse of Yugoslavia: Background and summary. Research paper 14, Parliamentary Research Service. Commonwealth of Australia.

Austin, A. (2003). Early warning and the field. Berghof Research Center for constructive conflict management. http://www.berghof-handbook.net.

Blau, P. (1977). Inequality and heterogeneity. New York: Free Press.

Blau, P., \& Schwartz, J. (1984). Crosscutting social circles. New York: Academic press.

Boguszak, M., \& Bozon, M. (1989). L’Homogamie sociale en Tchécoslovaquie. Population, 44, 198-209. doi: $10.2307 / 1533341$.

Botev, N. (1994). Where East meets West: Ethnic intermarriage in the former Yugoslavia, 1962 to 1989. American Sociological Review, 59, 461-480. doi:10.2307/2095944.

Bromlei, Y., \& Kashuba, M. (1982). Brak i semia u narodov Yugoslavii (Huwelijk en familie bij de Joegoslaven). Moskou: Nauka.

Burg, S. (1983). Conflict and cohesion in socialist Yugoslavia: Political decision making since 1966. Princeton NJ: Princeton University Press.

Coleman, D. (1985). Ethnic intermarriage in Great Britain. Population Trends, 40, 4-10.

Davis, J. L., \& Gurr, T. R. (1998). Preventive measures. Building risk assessment and crisis early warning systems. Lanham: Rowman \& Littlefield Publishers Inc. 
Drachsler, J. (1921). Intermarriage in New York City: A statistical study of the amalgamation of European peoples. New York: Columbia University.

Erikson, R., \& Goldthorpe, J. (1992). The constant flux. Oxford: Clarendon.

Gordon, M. (1964). Assimilation in American life. New York: Oxford University Press.

Gündüz-Hoşgör, A., \& Smits, J. (2002). Intermarriage between Turks and Kurds in contemporary Turkey. European Sociological Review, 18, 417-432. doi:10.1093/esr/18.4.417.

Hodson, R., Sekulic, D., \& Massey, G. (1994). National tolerance in former Yugoslavia. American Journal of Sociology, 99, 1534-1558. doi:10.1086/230453.

Hout, M. (1983). Mobility tables. Beverly Hills: Sage.

Jansen, C. (1982). Inter-ethnic marriages. International Journal of Comparative Sociology, 23, $225-235$. doi:10.1177/002071528202300306.

Johnson, R. (1980). Religious assortative marriage in the United States. New York: Academic Press.

Jones, F. (1991). Ethnic intermarriage in Australia, 1950-1952 to 1980-1982: Models or indices? Population Studies, 45, 27-42. doi:10.1080/0032472031000145066.

Jovic, D. (2001). The disintegration of Yugoslavia. A critical review of explanatory approaches. European Journal of Social Theory, 4, 101-120. doi:10.1177/13684310122225037.

Kalbach, M. A. (2002). Ethnic intermarriage in Canada. Canadian Ethnic Studies, 36, 25-39.

Kalmijn, M. (1991). Shifting boundaries: Trends in religious and educational homogamy. American Sociological Review, 56, 786-800. doi:10.2307/2096256.

Kalmijn, M. (1993). Trends in black/white intermarriage. Social Forces, 72, 119-146. doi:10.2307/2580162.

Kalmijn, M. (1998). Intermarriage and homogamy: Causes, patterns, trends. Annual Review of Sociology, 25, 395-421. doi:10.1146/annurev.soc.24.1.395.

Lee, S. (1988). Intermarriage and ethnic relations in Singapore. Journal of Marriage and the Family, 50, 255-265. doi:10.2307/352444.

Lévi-Strauss, C. (1969). The elementary structures of kinship. Boston: Beacon Press.

Lieberson, S., \& Waters, M. (1988). From many strands: Ethnic and racial groups in contemporary America. New York: Russell Sage.

Lu, H., \& Wong, R. (1998). Cohort trends in educational and ethnic intermarriage of Taiwan: Proceedings of the conference on Social Stratification and Mobility: Newly Industrializing Economies Compared. Taipei: Academia Sinica.

Meng, X., \& Gregory, R. G. (2005). Intermarriage and the economic assimilation of immigrants. Journal of Labor Economics, 23, 135-175. doi:10.1086/425436.

Merton, R. (1941). Intermarriage and social structure: Fact and theory. Psychiatry, 4, 361-374.

Monden, C., \& Smits, J. (2005). Ethnic intermarriage in times of social change: The case of Latvia. Demography, 42(2), 323-345. doi:10.1353/dem.2005.0015.

Munoz-Perez, F., \& Tribalat, M. (1984). Marriages d'étrangers et marriages mixtes en France. Population, 44, 427-462. doi:10.2307/1532897.

Pagnini, D., \& Morgan, S. (1990). Intermarriage and social distance among US immigrants at the turn of the century. American Journal of Sociology, 96, 405-432. doi:10.1086/229534.

Pesic, D., \& Janic, D. (1992). Nationalism and socialism. The case of Yugoslavia. History of European Ideas, 15, 210. doi:10.1016/0191-6599(92)90131-U.

Petrovic, R. (1986). Ethnically mixed marriages in Yugoslavia. Sociologija, 28(supp) 229-239.

Qian, Z. (1997). Breaking the racial barriers: Variations in interracial marriage between 1980 and 1990. Demography, 34, 263-276. doi:10.2307/2061704.

Qian, Z., \& Cobas, J. A. (2004). Latino's mate selection: National origin, racial, and nativity differences. Social Science Research, 33, 225-247. doi:10.1016/S0049-089X(03)00055-3.

Qian, Z., \& Lichter, D. T. (2001). Measuring marital assimilation: Intermarriage among natives and immigrants. Social Science Research, 30, 289-312. doi:10.1006/ssre.2000.0699.

Rieff, D. (1995). Slaughterhause. New York: Simon and Schuster.

Rosenfeld, M. J. (2002). Measures of assimilation in the marriage market: Mexican Americans 1970-1990. Journal of Marriage and the Family, 64, 152-162. doi:10.1111/j.1741-3737.2002.00152.x.

Savezni Zavod Statistiki. (1963, 1974, 1982, 1990) Demografska statistika. Beograd: Yugoslav Statistical Office.

Savezni Zavod Statistiki. (1991). Statisticki godisnjak SFRJ. Beograd: Yugoslav Statistical Ofice.

Schierup, C.-U. (1991). The post-communist enigma: Ethnic mobilization in Yugoslavia. New Community, $18,115-131$.

Schoen, R., \& Wooldredge, J. (1989). Marriage choices in North Carolina and Virginia, 1969-1971 and 1979-1981. Journal of Marriage and the Family, 51, 465-481. doi:10.2307/352508.

Sekulic, D., Massey, G., \& Hodson, R. (1994). Who were the Yugoslavs? American Sociological Review, 59, 83-97. doi:10.2307/2096134. 
Seroka, J. (1992). Nationalism and the new political compact in Yugoslavia. History of European Ideas, 15, 577-581. doi:10.1016/0191-6599(92)90065-K.

Shavit, Y., \& Stier, H. (1994). Ethnicity and education in Israel's changing marriage market. Paper presented at the 13th World Congress of Sociology (July, pp. 18-23). Bielefeld: Germany.

Simic, A. (1991). Obstacles to the development of a Yugoslav national consciousness: Ethnic identity and folk culture in the Balkans. Journal of Mediterranean Studies, 1, 18-38.

Tsai, S. (1996). The relative importance of ethnicity and education in Taiwan's changing marriage market. Proceedings of the National Science Council Part C: Humanities and the Social Sciences, 6(2), 301315.

Van den Berghe, P. (1979). Human family systems: An evolutionary view. New York: Elsevier.

Van Tubergen, F., \& Maas, I. (2007). Ethnic intermarriage among immigrants in the Netherlands. An analysis of population data. Social Science Research, 36, 1065-1086. doi:10.1016/j.ssresearch. 2006.09.003.

Vejvoda, I. (2004). Why did the war happened? In M. Hadžić (Ed.), The violent dissolution of Yugoslavia, causes, dynamics and effects (pp. 65-80). Belgrade: Centre for Civil-Military Relations.

Verstegen, S. (1999). Conflict prognostication: Toward a tentative framework for conflict assessment. The Hague: Clingendael.

WRR (1995) Stability and security in Europa. Report of the Netherlands Scientific Council for Government Policy, no. 48. The Hague: SDU. 